\title{
PENGGUNAAN METODE EKSPOSITORI PADA MATA PELAJARAN PAK DALAM MENINGKATKAN PRESTASI BELAJAR SISWA DI SD INPRES PONDANG
}

\author{
Olfie D. Koloy \\ SD INPRES Pondang \\ olfiedkoloy@gmail.com \\ Diterima 29 September 2019 \\ Disetujui 30 Oktober 2019
}

\begin{abstract}
In the learning process that involves material, methods, media props and so on must also experience changes towards renewal (innovation). Based on the problems seen, it is related to the improvement of Christian learning achievement by applying expository teaching models to grade VI students of SD Inpres Pondang. The purpose of this study in order to determine the increase in Christian learning achievement after applying expository teaching model. In this study using action research and data obtained from formative tests, observation sheets of teaching and learning activities of students. From the results of the study found that student achievement has increased from cycle I (51\%) to cycle II (89\%). Through this research it can be said that the expository teaching model can positively influence achievement, interest, attention and participation, learning motivation of SD Inpres Pondang students, and this learning model can be used as an alternative learning of Protestant Christianity.
\end{abstract}

Keywords: Expository Method, PAK, Learning Achievement and Pondang Inpres Elementary School.

\section{ABSTRAK}

Dalam proses pembelajaran yang menyangkut materi, metode, media alat peraga dan sebagainya harus juga mengalami perubahan kearah pembaharuan (inovasi). Berdasarkan permasalahan yang dilihat yaitu berkaitan dengan peningkatan prestasi belajar Agama Kristen dengan diterapkannya model pengajaran ekspositori pada siswa kelas VI SD Inpres Pondang. Tujuan dari penelitian ini dalam rangka mengetahui peningkatan prestasi belajar Agama Kristen setelah diterapkan model pengajaran ekspositori. Dalam penelitian ini menggunakan penelitian tindakan (action research) dan data diperoleh dari tes formatif, lembar observasi kegiatan belajar mengajar siswa. Dari hasil penelitian didapati bahwa prestasi belajar siswa mengalami peningkatan dari siklus I (51\%) sampai siklus II (89\%). Melalui penelitian ini dapat dikatakan bahwa model pengajaran ekspositori dapat berpengaruh positif terhadap prestasi, minat, perhatian dan partisipasi, motivasi belajar siswa SD Inpres Pondang, serta model pembelajaran ini dapat digunakan sebagai salah satu alternative pembelajaran Agama Kristen Protestan.

Kata Kunci: Metode Ekspositori, PAK, Prestasi Belajar dan SD Inpres Pondang.

\section{LATAR BELAKANG}

Pendidikan harus berorientasi sesuai dengan kondisi dan tuntutan itu, agar output pendidikan dapat mengikuti perkembangan yang terjadi. Dalam kondisi ini, manajemen birokratik sentralistik yang telah menghasilkan pola penyelenggaraan pendidikan yang seragam dalam berbagai kondisi lokal yang berbeda untuk berbagai lapisan masyarakat yang berbeda, tidak bisa dipertahankan lagi. Dikatakan demikian, karena muatan dan proses pembelajaran di sekolah selama ini menjadi miskin variasi, berbasis pada standar nasional yang kaku, dan diimplementasikan di sekolah atas dasar petunjuk-petunjuk yang cenderung 
serba detail. Di samping itu, peserta didik dievaluasi atas dasar akumulasi pengetahun yang telah diperolehnya, sehingga orang tua tidak mempunyai variasi pilihan atas jasa pelayanan pendidikan bagi anakanaknya, sumber-sumber pembelajaran di "dunia" nyata dan unggulan daerah tidak dimanfaatkan bagi kepentingan pendidikan di sekolah, dan lulusan hanya mampu menghafal tanpa memahami.

Pendidikan formal saat ini ditandai dengan adanya perubahan yang berkali-kali dalam beberapa tahun terakhir ini ditandai dengan adanya suatu perubahan (inovasi). Perubahan pada hakekatnya adalah sesuatu hal yang wajar karena perubahan itu adalah sesuatu yang bersifat kodrati dan manusiawi. Hanya ada dua alternatif pilihan yaitu menghadapi tantangan yang ada di dalamnya atau mencoba menghindarinya. Jika perubahan direspon positif akan menjadi peluang dan jika perubahan direspon negatif akan menjadi arus kuat yang menghempaskan dan mengalahkan kita.

Dalam proses pembelajaran yang menyangkut materi, metode, media alat peraga dan sebagainya harus juga mengalami perubahan kearah pembaharuan (inonvasi). Dengan adanya inovasi tersebut di atas dituntut seorang guru untuk lebih kreatif dan inovatif, terutama dalam menentukan model dan metode yang tepat akan sangat menentukan keberhasilan siswa terutama pembentukan kecakapan hidup (life skill) siswa yang berpijak pada lingkungan sekitarnya.

Seperti juga yang pendapat Musyaddad (2013) dalam dalam penelitian dari Syamsuar \& Reflianto (2019) di dalam penelitiannya yaitu pengunggkapan bahwa relevansi pendidikan dalam hal subtansi dengan kebutuhan masyarakat masih tergolong rendah. Ada juga yang dijadikan sebuah bagian dari politik oleh para pemangku kepentingan.

SD Inpres Pondang menjadi lokus penelitian karena melihat belum banyak yang melaksanakan penelitian di tempat ini dan merasa begitu penting untuk melaksanakan penelitian ini, dalam rangka memberikan kontribusi ke pihak sekolah dan bisa menjadi referensi kepada guruguru di sekolah tersebut.

\section{METODE PENELITIAN.}

Penelitian ini merupakan penelitian tindakan (action research), karena penelitian dilakukan untuk memecahkan masalah pembelajaran di kelas. Penelitian ini juga termasuk penelitian deskriptif, sebab menggambarkan bagaimana suatu teknik pembelajaran diterapkan dan bagaimana hasil yang diinginkan dapat dicapai. Dalam penelitian ini menggunakan bentuk guru sebagai peneliti, dimana guru sangat berperan sekali dalam proses penelitian tindakan kelas. Dalam bentuk ini, 
tujuan utama penelitian tindakan kelas ialah untuk meningkatkan praktik-praktik pembelajaran di kelas. Dalam kegiatan ini, guru terlibat langsung secara penuh dalam proses perencanaan, tindakan, observasi, dan refleksi. Kehadiran pihak lain dalam penelitian ini peranannya tidak dominan dan sangat kecil.

Tempat penelitian adalah tempat yang digunakan dalam melakukan penelitian untuk memperoleh data yang diinginkan. Penelitian ini bertempat di SD INPRES Pondang Tahun Pelajaran 2017/2018. Waktu penelitian adalah waktu berlangsungnya penelitian atau saat penelitian ini dilangsungkan. Penelitian ini dilaksanakan pada bulan Agustus semester ganjil 2017/2018.

Kegiatan yang dilakukan dalam tahap persiapan ini adalah mempersiapkan segala sesuatu yang berhubungan dengan pelaksanaan penelitian. Dalam kegiatan ini diharapkan pelaksanaan penelitian akan berjalan lancer dan mencapai tujuan yang diinginkan. Kegiatan persiapan ini meliputi: (1) kajian pustaka, (2) pengurusan administrasi perijinan, (3) penyusunan rancangan penelitian, (4) orientasi lapangan, dan (5) penyusunan instrumen penelitian. Alat pengumpul data dalam penelitian ini adalah tes buatan guru yang fungsinya adalah: (1) Untuk menentukan seberapa baik siswa telah menguasai bahan pelajaran yang diberikan dalam waktu tertentu; (2) Untuk menentukan apakah suatau tujuan telah tercapai; dan (3) Untuk memperoleh suatu nilai (Arikunto, Suharsimi, 2002:149). Sedangkan tujuan dari tes adalah untuk mengetahui ketuntasan belajar siswa secara individual maupun secara klasikal. Disamping itu untuk mengetahui letak kesalahankesalahan yang dilakukan siswa sehingga dapat dilihat dimana kelemahannya, khususnya pada bagian mana TPK yang belum tercapai. Untuk memperkuat data yang dikumpulkan maka juga digunakan metode observasi (pengamatan) yang dilakukan sendiri oleh guru untuk mengetahui dan merekam aktivitas siswa dalam proses belajar mengajar. Dalam rangka menyusun dan mengolah data yang terkumpul sehingga dapat mengahsilkan suatu kesimpulan yang dapat dipertanggungjawabkan, maka digunakan analisis data kuantitatif dan pada metode observasi digunakan data kualitatif. Cara perhitungan untuk mengetahui ketuntasan belajar siswa dalam proses belajar mengajar sebagai berikut: Merekapitulasi hasil tes, Merekapitulasi hasil pengamatan, Menghitung jumlah skor yang tercapai dan prosentasenya untuk masing-masing siswa dengan menggunakan rumus ketuntasan belajar seperti yang terdapat dalam buku petunjuk teknis penilaian yaitu siswa dikatakan tuntas secara individual jika mendapatkan nilai minimal 75 , sedangkan 
secara klasikal dikatakan tuntas belajar jika jumlah siswa yang tuntas secara individu mencapai $85 \%$ yang telah mencapai daya serap lebih dari sama dengan $75 \%$.

\section{HASIL PENELITIAN DAN}

\section{PEMBAHASAN}

Data penelitian yang diperoleh berupa data observasi pengamatan pengelolaan model pengajaran ekspositori dan pengamatan aktivitas siswa dan guru pada akhir pembelajaran, dan data tes formatif siswa pada setiap siklus.

Data lembar observasi diambil dari dua pengamatan yaitu data pengamatan pengelolaan model pengajaran ekspositori yang digunakan untuk mengetahui pengaruh penerapan model pengajaran ekspositori dalam meningkatkan prestasi belajar siswa dan data pengamatan aktivitas siswa dan guru serta data pengamatan minat, keterlibatan, dan partisipasi siswa dalam mengikuti kegiatan belajar mengajar.

Data tes formatif untuk mengetahui peningkatan prestasi belajar siswa setelah diterapkan proses belajar mengajar dengan menerapkan model pengajaran ekspositori.

A. Analisis Data Penelitian Persiklus

1. Siklus I

a. Tahap Perencanaan

Pada tahap ini peneliti mempersiapkan perangkat pembelajaran yang terdiri dari rencana pelajaran 1 , soal tes formatif 1 dan alat-alat pengajaran yang mendukung. Selain itu juga dipersiapkan lembar observasi pengolahan model pengajaran ekspositori, dan lembar observasi aktivitas guru dan siswa.

b. Tahap Kegiatan dan Pelaksanaan

Pelaksanaan kegiatan belajar mengajar untuk siklus I dilaksanakan pada tanggal 6 Agustus 2017 di Kelas VI dengan jumlah siswa 35 siswa. Dalam hal ini peneliti bertindak sebagai pengajar, sedangkan yang bertindak sebagai pengamat adalah wali kelas VI dengan dibantu oleh seorang guru. Adapun proses belajar mengajar mengacu pada rencana pelajaran yang telah dipersiapkan. Pengamatan (observasi) dilaksanakan bersamaan dengan pelaksaaan belajar mengajar.

Pada akhir proses belajar mengajar siswa diberi tes formatif I dengan tujuan untuk mengetahui tingkat keberhasilan siswa dalam proses belajar mengajar yang telah dilakukan. Adapun data hasil penelitian pada siklus I adalah sebagai berikut:

Tabel 4.1. Rekapitulasi Hasil Tes Formatif Siswa Pada Siklus I

\begin{tabular}{|l|l|l|}
\hline No & Uraian & $\begin{array}{l}\text { Hasil } \\
\text { Siklus I }\end{array}$ \\
\hline 1 & $\begin{array}{l}\text { Nilai rata-rata tes } \\
\text { formatif }\end{array}$ & 75,93 \\
2 & 18 \\
\hline
\end{tabular}




\begin{tabular}{|l|l|l|}
\hline 3 & $\begin{array}{l}\text { Jumlah siswa yang } \\
\text { tuntas belajar }\end{array}$ & \\
& $\begin{array}{l}\text { Persentase ketuntasan } \\
\text { belajar }\end{array}$ & \\
\hline
\end{tabular}

Dari tabel di atas dapat dijelaskan bahwa dengan menerapkan model pengajaram kolaborasi diperoleh nilai ratarata prestasi belajar siswa adalah 75,93 dan ketuntasan belajar mencapai $51 \%$ atau ada 18 siswa dari 35 siswa sudah tuntas belajar. Hasil tersebut menunjukkan bahwa pada siklus pertama secara klasikal siswa belum tuntas belajar, karena siswa yang memperoleh nilai $\geq 75$ hanya sebesar $51 \%$ lebih kecil dari persentase ketuntasan yang dikehendaki yaitu sebesar $85 \%$. Hal ini disebabkan karena siswa masih merasa baru dan belum mengerti apa yang dimaksudkan dan digunakan guru dengan menerapkan model pengajaram kolaborasi.

c. Analilisis Data Minat, Perhatian, Partisipasi

\section{1) Minat}

Dari analisis data diperoleh hasil sebanyak 20 siswa $(57,14 \%)$ memiliki minat baik, 8 siswa $(22,86 \%)$ memiliki minat cukup, 8 siswa $(22,86 \%)$ memiliki minat kurang .

\section{2) Perhatian}

Dari analisis data diperoleh hasil sebanyak 20 siswa $(57,14 \%)$ memiliki perhatian baik, 7 siswa $(20,00 \%)$ memiliki perhatian cukup, 8 siswa $(22,86 \%)$ memiliki perhatian kurang.

3) Partisipasi

Dari analisis data diperoleh hasil sebanyak 19 siswa $(54,28 \%)$ memiliki partisipasi baik, 8 siswa $(22,86 \%)$ memiliki partisipasi cukup, 8 siswa $(22,86 \%)$ memiliki partisipasi kurang.

\section{d. Refleksi}

Dalam pelaksanaan kegiatan belajar mengajar diperoleh informasi dari hasil pengamatan sebagai berikut:

1) Guru kurang maksimal dalam memotivasi siswa dan dalam menyampaikan tujuan pembelajaran

2) Guru kurang maksimal dalam pengelolaan waktu

3) Siswa kurang aktif selama pembelajaran berlangsung

e. Refisi

Pelaksanaan kegiatan belajar mengajar pada siklus I ini masih terdapat kekurangan, sehingga perlu adanya revisi untuk dilakukan pada siklus berikutnya.

1) Guru perlu lebih terampil dalam memotivasi siswa dan lebih jelas dalam menyampaikan tujuan pembelajaran. Dimana siswa diajak untuk terlibat langsung dalam setiap kegiatan yang akan dilakukan.

2) Guru perlu mendistribusikan waktu secara baik dengan menambahkan informasi-informasi yang dirasa perlu dan memberi catatan 
3) Guru harus lebih terampil dan bersemangat dalam memotivasi siswa sehingga siswa bisa lebih antusias.

2. Siklus II

a. Tahap Perencanaan

Pada tahap ini peneliti mempersiapkan perangkat pembelajaran yang terdiri dari rencana pelajaran 3 , soal tes formatif 3 dan alat-alat pengajaran yang mendukung. Selain itu juga dipersiapkan lembar observasi pengelolaan model pengajaran ekspositori dan lembar observasi aktivitas guru dan siswa.

b. Tahap kegiatan dan pengamatan

Pelaksanaan kegiatan belajar mengajar untuk siklus II dilaksanakan pada tanggal 20 Agustus 2017 di Kelas VI dengan jumlah siswa 35 siswa. Dalam hal ini peneliti bertindak sebagai pengajar, sedangkan yang bertindak sebagai pengamat adalah wali kelas VI dengan dibantu oleh seorang guru. Adapun proses belajar mengajar mengacu pada rencana pelajaran dengan memperhatikan revisi pada siklus I, sehingga kesalahan atau kekurangan pada siklus II tidak terulang lagi pada siklus II. Pengamatan (observasi) dilaksanakan bersamaan dengan pelaksanaan belajar mengajar.

Pada akhir proses belajar mengajar siswa diberi tes formatif II dengan tujuan untuk mengetahui tingkat keberhasilan siswa dalam proses belajar mengajar yang telah dilakukan. Instrumen yang digunakan adalah tes formatif II. Adapun data hasil penelitian pada siklus II adalah sebagai berikut:

Tabel 4.2 Hasil Tes Formatif Siswa pada Siklus II

\begin{tabular}{|l|l|l|}
\hline No & Uraian & $\begin{array}{l}\text { Hasil } \\
\text { Siklus II }\end{array}$ \\
\hline 1 & Nilai rata-rata tes & 88,83 \\
2 & $\begin{array}{l}\text { formatif } \\
3\end{array}$ & 31 \\
& $\begin{array}{l}\text { Jumlah siswa yang } \\
\text { Puntas belajar } \\
\text { Persentase ketuntasan }\end{array}$ & 89 \\
\hline
\end{tabular}

Berdasarkan tabel diatas diperoleh nilai rata-rata tes formatif sebesar 88,83 dan dari 35 siswa yang telah tuntas sebanyak 31 siswa dan 4 siswa belum mencapai ketuntasan belajar. Maka secara klasikal ketuntasan belajar yang telah tercapai sebesar 89\% (termasuk kategori tuntas). Hasil pada siklus II ini mengalami peningkatan lebih baik dari siklus II. Adanya peningkatan hasil belajar pada siklus II ini dipengaruhi oleh adanya peningkatan kemampuan guru dalam menerapkan model pengajaran ekspositori sehingga siswa menjadi lebih terbiasa dengan pembelajaran seperti ini sehingga siswa lebih mudah dalam memahami materi yang telah diberikan.

$$
\text { c. Analilisis Data Minat, }
$$

Perhatian, Partisipasi 
1) Minat

Dari analisis data diperoleh hasil sebanyak 26 siswa $(80,00 \%)$ memiliki minat baik, 4 siswa $(11,43 \%)$ yang memiliki minat cukup, 3 siswa $(8,57 \%)$ memiliki minat kurang.

2) Perhatian

Dari analisis data diperoleh hasil sebanyak 26 siswa $(74,28 \%)$ memiliki perhatian baik, 6 siswa $(17,14 \%)$ memiliki perhatian cukup, 3 siswa $(8,57 \%)$ memiliki perhatian kurang.

\section{3) Partisipasi}

Dari analisis data diperoleh hasil sebanyak 24 siswa $(68,57 \%)$ memiliki partisipasi baik, 8 siswa $(22,85 \%)$ memiliki partisipasi cukup, 3 siswa $(8,57 \%)$ memiliki partisipasi kurang.

\section{d. Refleksi}

Pada tahap ini akah dikaji apa yang telah terlaksana dengan baik maupun yang masih kurang baik dalam proses belajar mengajar dengan penerapan model pengajaran ekspositori. Dari data-data yang telah diperoleh dapat duraikan sebagai berikut:

1) Selama proses belajar mengajar guru telah melaksanakan semua pembelajaran dengan baik. Meskipun ada beberapa aspek yang belum sempurna, tetapi persentase pelaksanaannya untuk masing-masing aspek cukup besar.
2) Berdasarkan data hasil pengamatan diketahui bahwa siswa aktif selama proses belajar berlangsung.

3) Kekurangan pada siklussiklus sebelumnya sudah mengalami perbaikan dan peningkatan sehingga menjadi lebih baik.

4) Hasil belajar siswsa pada siklus II mencapai ketuntasan.

e. Revisi Pelaksanaan

Pada siklus II guru telah menerapkan model pengajaran ekspositori dengan baik dan dilihat dari aktivitas siswa serta hasil belajar siswa pelaksanaan proses belajar mengajar sudah berjalan dengan baik. Maka tidak diperlukan revisi terlalu banyak, tetapi yang perlu diperhatikan untuk tindakan selanjutnya adalah memaksimalkan dan mempertahankan apa yang telah ada dengan tujuan agar pada pelaksanaan proses belajar mengajar selanjutnya penerapan model pengajaran ekspositori dapat meningkatkan proses belajar mengajar sehingga tujuan pembelajaran dapat tercapai.

\section{B. Pembahasan}

1. Ketuntasan Hasil belajar Siswa

Melalui hasil penelitian ini menunjukkan bahwa model pengajaran ekspositori memiliki dampak positif dalam meningkatkan prestasi belajar siswa. Hal ini dapat dilihat dari semakin mantapnya 
pemahaman siswa terhadap materi yang disampaikan guru (ketuntasan belajar meningkat dari siklus I, dan II) yaitu masing-masing 51\%, dan $89 \%$. Pada siklus II ketuntasan belajar siswa secara klasikal telah tercapai.

2. Kemampuan Guru dalam Mengelola Pembelajaran

Berdasarkan analisis data, diperoleh aktivitas siswa dalam proses belajar mengajar dengan menerapkan model pengajaran ekspositori dalam setiap siklus mengalami peningkatan. Hal ini berdampak positif terhadap prestasi belajar siswa yaitu dapat ditunjukkan dengan meningkatnya nilai rata-rata siswa pada setiap siklus yang terus mengalami peningkatan.

3. Aktivitas Guru dan Siswa Dalam Pembelajaran

Berdasarkan analisis data, diperoleh aktivitas siswa dalam proses pembelajaran Agama Kristen pada pada pokok bahasan masuknya Konsep Ibadah Sebagai Kegiatan Ritual dengan model pengajaran ekspositori yang paling dominan adalah bekerja dengan sesama anggota kelompok, mendengarkan/memperhatikan penjelasan guru, dan diskusi antar siswa/antara siswa dengan guru. Jadi dapat dikatakan bahwa aktivitas siswa dapat dikategorikan aktif.

Sedangkan untuk aktivitas guru selama pembelajaran telah melaksanakan langkah-langkah kegiatan belajar mengajar dengan menerapkan pengajaran ekspositori dengan baik. Hal ini terlihat dari aktivitas guru yang muncul di antaranya aktivitas membimbing dan mengamati siswa dalam menemukan konsep, menjelaskan materi yang sulit, memberi umpan balik/evaluasi/tanya jawab dimana prosentase untuk aktivitas di atas cukup besar.

4. Analilisis Data Minat, Perhatian, Partisipasi

a. Minat

Dari analisis data pada siklus I diperoleh hasil sebanyak 20 siswa $(57,14 \%)$ memiliki minat baik, 8 siswa $(22,86 \%)$ memiliki minat cukup, 8 siswa $(22,86 \%)$ memiliki minat kurang, pada siklus II diperoleh hasil sebanyak 26 siswa $(80,00 \%)$ memiliki minat baik, 3 siswa $(8,57 \%)$ yang memiliki minat cukup, 3 siswa $(8,57 \%)$ memiliki minat kurang. Dari hasil ini dapat disimpulkan bahwa kegiatan pembelajaran Agama Kristen dengan menerapkan model pengajaram ekspositori dapat meningkatkan minat siswa terhadap pembelajaran.

b. Perhatian

Dari analisis data pada siklus I diperoleh hasil sebanyak 20 siswa $(57,14 \%)$ memiliki perhatian baik, 8 siswa $(22,86 \%)$ memiliki perhatian cukup, 8 siswa $(22,86 \%)$ memiliki perhatian kurang, pada siklus II diperoleh hasil 26 siswa $(74,28 \%)$ memiliki perhatian baik, 6 siswa $(17,14 \%)$ memiliki perhatian cukup, 3 siswa $(8,57 \%)$ 
memiliki perhatian kurang. Dari hasil ini dapat diinterpretasikan bahwa kegiatan pembelajaranAgama Kristen dengan menerapkan model pengajaran ekspositori dapat meningkatkan perhatian siswa terhadap pembelajaran.

c. Partisipasi

Dari analisis data pada siklus I diperoleh hasil sebanyak 17 siswa $(51,13 \%)$ memiliki partisipasi baik, 8 siswa $(22,86 \%)$ memiliki partisipasi cukup, 8 siswa $(22,86 \%)$ memiliki partisipasi kurang, siklus II diperoleh hasil 24 siswa $(68,57 \%)$ memiliki partisipasi baik, 8 siswa $(22,85 \%)$ memiliki partisipasi cukup, 3 siswa $(8,57 \%)$ memiliki partisipasi kurang. Dari hasil ini dapat diinterpretasikan bahwa kegiatan pembelajaran Agama Kristen dengan menerapkan model pengajaran ekspositori dapat meningkatkan partisipasi siswa terhadap pembelajaran.

Ada pendapat dari Daryano \& Karim (2017) berkaitan dengan pemaknaan pendidikan yang di katakan bahwa, memungkinkan para sisiwa untuk mampu beradaptasi dari setiap proses pengalaman belajar dengan mengintegrasikan tool dan sumber digital demi memotivasi dan mengembangkan kreatifitas dalam lingkungan belajar yang bernuansa teknologi, sehingga dapat menimbulkan rasa ingin tahu dan mudah dilibatkan dalam proses pembelajaran bagi dirinya yang sesuai dengan minat dan kebutuhan serta tantangan yang dihadapi sehingga peserta didik merasakan kostumisasi dan personalisasi dalam aktivitas belajarnya. Berkaitan dengan perkembangan teknologi informasi yang berpotensi menimbulkan disrupsi, pemikiran Emile Durkheimtentang moralitas, terutama terkait moralitas kolektif tidak dapat diabaikan karena amanat yang diemban sistem pendidikan nasional adalah untuk meningkatkan keimanan dan ketakwaan kepada Tuhan Yang Maha Esa serta akhlak mulia dalam rangka mencerdaskan kehidupan bangsa seperti yang ditetapkan dalam Undang-undang Republik Indonesia Nomor 20 Tahun 2003 tentang Sistem Pendidikan Nasional.

Penting juga melihat pendapat dari Suyitno (2004), yang mengatakan bahwa metode ekspositori ialah cara penyampaian pelajaran dari seorang guru kepada siswa di kelas dengan cara berbicara pada awal pembelajaran, menerangkan materi, memberikan contoh soal disertai tanya jawab dan siswa hanya mendengarkan dan membuat catatan. Metode ekspositori merupakan salah satu metode pembelajaran yang memungkinkan siswa belajar secara maksimal untuk memecahkan masalah.

$$
\text { Yuswohadi (2020) lebih }
$$
menekankan bahwa, sekolah tradisional sebagai wahana pembelajaran akan tergeser dari posisi "core" menjadi "peripheral" sehingga proses pembelajaran tidak hanya 
berlangsung di kelas melainkan juga dilakukan anytime, anywhere, any platform/device termasuk peran guru yang tidak hanya berada di kelas tetapi pelbagai sumber belajar merupakan guru yang diperankan oleh $\mathrm{AI}$ atau $\mathrm{AR} / \mathrm{VR}$

\section{KESIMPULAN}

Berdasarkan hasil penelitian yang telah dipaparkan selama tiga siklus, hasil seluruh pembahasan serta analisis yang telah dilakukan dapat disimpulkan bahwa, model pengajaran ekspositori dapat meningkatkan kualitas pembelajaran Agama Kristen. Model pengajaram ekspositori memiliki dampak positif dalam meningkatkan prestasi belajar siswa yang ditandai dengan peningkatan ketuntasan belajar siswa dalam setiap siklus, yaitu siklus I (51\%), dan siklus II (89\%). Siswa dapat bekerja secara mandiri maupun kelompok, serta mampu mempertangungjawabkan segala tugas individu maupun kelompok. Penerapan model pengajaram ekspositori mempunyai pengaruh positif, yaitu dapat meningkatkan motivasi, minat perhatian serta partisipasi belajar siswa.

\section{DAFTAR PUSTAKA}

Arikunto, Suharsimi. 2002. Prosedur Penelitian Suatu Pendekatan Praktek. Jakarta: Rineksa Cipta.
Syamsuar, and Reflianto. "Pendidikan Dan

Tantangan Pembelajaran Berbasis

Teknologi Informasi Di Era Revolusi

Industri 4.0." Pendidikan Dan

Tantangan Pembelajaran Berbasis

Teknologi Informasi Di Era Revolusi

Industri 4.0 6, no. 2 (2019).

Daryanto and Syaiful Karim. 2017,

Pembelajaran Abad 21, Gaya Media

(Yogyakarta: Penerbit Gava Media)

Suyitno, A. 2004. Dasar-dasar dan Proses

Pembelajaran Matematika 1.

Semarang: Unnes

Yuswohadi. 2020 "Nadiem Dan

Disrupsi Pendidikan Kita.” Accessed May 18 ,

https://www.yuswohady.com/2019/10/25/

nadiem-dan-disrupsi-pendidikan-kita/ 